\title{
Sources of childhood and adult resilience and their impact on harms associated with adverse childhood experiences
}

Hughes, Karen; Ford, Katharine; Bellis, Mark

\section{Injury Prevention}

\section{DOI:}

10.1136/injuryprevention-2018-safety.304

Published: 01/11/2018

Peer reviewed version

Cyswllt i'r cyhoeddiad / Link to publication

Dyfyniad o'r fersiwn a gyhoeddwyd / Citation for published version (APA):

Hughes, K., Ford, K., \& Bellis, M. (2018). Sources of childhood and adult resilience and their impact on harms associated with adverse childhood experiences. Injury Prevention, 24(Supplement 2), A110. https://doi.org/10.1136/injuryprevention-2018-safety.304

\footnotetext{
Hawliau Cyffredinol / General rights

Copyright and moral rights for the publications made accessible in the public portal are retained by the authors and/or other copyright owners and it is a condition of accessing publications that users recognise and abide by the legal requirements associated with these rights.

- Users may download and print one copy of any publication from the public portal for the purpose of private study or research.

- You may not further distribute the material or use it for any profit-making activity or commercial gain

- You may freely distribute the URL identifying the publication in the public portal ?
}

Take down policy

If you believe that this document breaches copyright please contact us providing details, and we will remove access to the work immediately and investigate your claim. 


\section{Sources of childhood and adult resilience and their impact on harms associated with adverse childhood experiences}

Hughes $\mathrm{K}^{1, *}$, Ford $\mathrm{K}^{2}$, Bellis $\mathrm{MA}^{3}$.

${ }^{1}$ Research Capacity and Development Manager, Public Health Wales, Wales. ${ }^{2}$ Research Officer, School of Healthcare Sciences, Bangor University, Wales. ${ }^{3}$ Directory of the Policy, Research and International Development Directorate, Public Health Wales, Wales.

*Corresponding and presenting author

Scholarship funding not required

\section{Background}

Adverse childhood experiences (ACEs; i.e. child maltreatment, household dysfunction) have widereaching impacts and are strong predictors of poor outcomes in adults. However, many individuals who experience ACEs avoid or overcome their associated problems. The factors which effectively promote resilience against ACEs are still largely unknown.

\section{Objective}

This research sought to understand what contributes to an individual's resilience and how much resilience offers protection from the negative effects of ACEs.

\section{Methods}

A face-to-face household survey was conducted with 2,497 residents aged 18-69 in Wales, United Kingdom, from March-June 2017. The survey explored: exposure to 11 ACEs; access to childhood and adult resilience resources, health-related behaviours and health outcomes.

\section{Findings}

Half of all adults reported at least one ACE, $14 \%$ had four or more. ACEs were strongly associated with worse health outcomes, for example, individuals with 4+ ACEs being four times more likely to report current mental illness, 6 times more likely to report lifetime mental illness and over nine times more likely to have ever felt suicidal or self-harmed. Childhood and adulthood resilience were strongly associated with better health outcomes in those both with and without ACEs. Resilience resources associated with better outcomes for mental illness included, in childhood: sports participation and having a trusted adult relationship; and as adults: sports/community group participation, enjoying culture/traditions, financial security, and higher perceived support from public services and employers.

\section{Conclusion and policy implications}

ACEs are common and represent a significantly increased risk of poor health across the life-course. Supporting individuals affected by childhood adversity is vital to improve population health. Building resilience can moderate the increased risk to health that ACEs pose. However, resilience resources do not entirely counter ACE-related harms, thus work should be directed at the prevention of ACEs to ensure the provision of positive childhood environments for future generations.

\section{Sub-theme}

3.3 Child maltreatment, implementation of Convention on Child Right 
key word(s) Resilience Child maltreatment, violence, adverse childhood experiences 